\title{
KETANGGUHAN MAHASISWA YANG BERWIRAUSAHA: STUDI KASUS
}

\author{
Osi Isna Sabela, Jati Ariati, Imam Setyawan* \\ Fakultas Psikologi Universitas Diponegoro \\ Jl. Prof. Soedharto SH, Tembalang, Semarang 50275 \\ *imamsetyawan.psiundip@gmail.com
}

\begin{abstract}
Hardiness is a character that can influence how individual views their stress and determines an efefctive response towards stress. This study aims to explore the hardiness of college students who were also enterpreneurs. This study used a qualitative-case study method that applied observation and interview methods to collect data. Two undergraduate students joined the study. They started their businesses since they were a freshman and their bussinesses were still well-maintained until the time of study. The results showed that hardiness plays important role in dealing with stressful events due to their double roles as a student as well as an enterpreneur. These enterpreneur students could apply effective coping strategies to solve various problems. Hardiness enables individual to have opportunities to control their lives, to be more energic and enthusiastic, to be more involved in all things they do, and believes that they are ebale to make changes in a positive ways. Hardiness convinced these enterpreneur students to take enterpreneurship as their life path and encouraged them to make efforts to grow their businesses.
\end{abstract}

Keywords: hardiness, enterpreuner, college students

\begin{abstract}
Abstrak
Ketangguhan merupakan salah satu karakter yang dapat mempengaruhi cara pandang seseorang terhadap stres yang dihadapinya dan menentukan respon yang efektif. Penelitian ini bertujuan untuk mengetahui ketangguhan pada mahasiswa yang juga berwirausaha. Penelitian ini menggunakan metode kualitatif-studi kasus dengan mengunakan wawancara dan observasi dalam mengumpulkan data. Subjek penelitian adalah dua orang mahasiswa S1, yang merintis usaha ketika menjadi mahasiswa, dan usaha yang dilakukannya dapat bertahan dan berkembang. Hasil penelitian ini menunjukkan bahwa ketangguhan memegang peranan penting dalam menghadapi situasi stres karena peran ganda sebagai mahasiswa sekaligus wirausaha. Mahasiswa wirausaha akan dapat menggunakan strategi coping yang efektif untuk mengatasi berbagai permasalahan yang dihadapi. Ketangguhan membuat individu memiliki kesempatan untuk mengontrol jalan hidup, menjadi lebih antusias dan energik, menjadi lebih terlibat pada apa saja yang dilakukannya, dan yakin dapat membuat suatu perubahan ke arah positif. Ketangguhan membuat mahasiswa wirausaha semakin yakin untuk menetapkan wirausaha sebagai jalan hidupnya dan bersemangat untuk melakukan upaya pengembangan-pengembangan usaha hingga usaha yang dirintisnya menjadi besar.
\end{abstract}

Kata kunci: ketangguhan, wirausaha, mahasiswa

\section{PENDAHULUAN}

Minat alumnus perguruan tinggi menjadi wirausaha sangat minim. Sebagian besar lulusan perguruan tinggi lebih memilih menjadi pencari kerja daripada pencipta lapangan kerja. Puluhan ribu sarjana yang merupakan lulusan baru, hanya sekitar $17 \%$ yang berminat untuk berwirausaha.
Hal tersebut disebabkan karena penghasilan yang tak menentu, risiko yang terlalu besar, dan tidak memiliki modal. Kondisi tersebut tentunya kurang mendukung program pemerintah untuk mengurangi angka pengangguran kalangan terdidik dari perguruan tinggi (Irwandi,2008). 
Menurut data dari Biro Pusat Statistik pada Agustus 2010, jumlah pengangguran terbuka adalah sebanyak 8.319.779 dan sebanyak 1.153.350 merupakan lulusan perguruan tinggi. Memasuki 2011 pengangguran terbuka sudah mencapai angka 9.250.000 (Anonim, 2011). Realitas tersebut menunjukkan bahwa tingkat pengangguran di Indonesia masih sangat tinggi yang tidak berimbang dengan ketersediaan lapangan pekerjaan.

Salah satu upaya menurunkan angka pengangguran yang bersumber pada jumlah lulusan perguruan tinggi adalah dengan mempersiapkan mahasiswa untuk memiliki jiwa wirausaha. Berwirausaha merupakan salah satu pilihan rasional mengingat sifatnya yang mandiri, karena tidak tergantung pada ketersediaan lapangan kerja yang ada, serta mampu menjembatani kesenjangan antara ilmu pengetahuan dan pasar (Hisrich, Peters \& Sheperd, 2008). Wirausaha juga merupakan penyumbang pajak bagi pemerintah, APBN Indonesia $70 \%$ lebih dibiayai oleh pajak. Jumlah wirausaha yang semakin banyak, akan menambah penerimaan negara dan meningkatkan pertumbuhan ekonomi di Indonesia (Uno, 2008).

Kewirausaahaan tidak semata-mata berkaitan dengan soal bisnis dan perdagangan. Kewirausahaan dapat diartikan sebagai semangat, sikap, perilaku dan kemampuan individu dalam menangani usaha dan atau kegiatan yang mengarah pada upaya mencari, menciptakan, menerapkan cara kerja teknologi dan produk baru dengan meningkatkan efisiensi dalam rangka memberikan pelayanan yang lebih dan memperoleh keuntungan yang besar (Anoraga \& Sudantoko, 2002). Wirausaha adalah seseorang yang jeli menemukan peluang usaha, mendirikan, mengelola, mengembangkan, dan melembagakan usahanya, di mana kelangsungan hidupnya tergantung pada tindakannya sendiri (Riyanti, 2003).

Minimnya jumlah wirausaha membuat berbagai pihak, mulai dari pemerintah, akademisi perguruan tinggi yang merupakan ujung tombak pencetak caloncalon penerus bangsa, dan pihak-pihak yang peduli terhadap masa depan bangsa menggalakkan isu kewirausahaan. Beberapa perguruan tinggi menyelenggarakan berbagai workshop, seminar, kuliah umum, kompetisi bertema kewirausahaan. Pemerintah juga tidak kalah memberikan perhatian. Kementrian Pendidikan Nasional melalui Direktorat Jendral Pendidikan Tinggi (DIKTI) meluncurkan berbagai program untuk mendukung pengembangan kewirausahaan di perguruan tinggi. Salah satunya adalah Program Wirausaha Mahasiswa (PMW) dengan bentuk kegiatan yang meliputi pendidikan dan pelatihan kewirausahaan, magang, penyusunan rencana bisnis, dukungan permodalan, pendampingan usaha, sampai dengan monitoring dan evaluasi (Irwandi,_2008).

Upaya yang dilakukan perguruan tinggi yang bekerja sama dengan pemerintah dan berbagai pihak untuk menstimulasi mahasiswa berwirausaha sayangnya tidak serta merta meningkatkan jumlah wirausaha mahasiswa dilihat dari segi kualitasnya. Banyak mahasiswa penerima bantuan modal usaha yang gagal dan berhenti meneruskan bisnisnya karena berbagai kendala (sulitnya membagi waktu, kurangnya kemampuan manajerial, sulit mempromosikan dan mengembangkan usahanya), sedangkan mahasiswa lainnya hanya sebatas pada minat dan ketertarikan untuk berwirausaha tanpa aksi yang nyata. 
Berdasarkan evaluasi dari Program Mahasiswa Wirausaha (PMW) Universitas Diponegoro tahun 2009, didapatkan bahwa beberapa penerima bantuan modal menyalahgunakan bantuan modal yang diberikan, beberapa di antaranya tidak menjalankan usaha sebagaimana mestinya, bahkan terdapat kelompok yang berhenti di tengah jalan (Anonim, 2011). Mahasiswa pada umumnya kurang memiliki etos dan budaya kerja yang menggambarkan semangat kewirausahaan. Nilai-nilai yang ditanamkan dalam mata kuliah kewirausahaan belum sepenuhnya terinternalisasi, sehingga pemberian bantuan modal tidak memberikan banyak solusi.

Tidak semua mahasiswa yang mencoba terjun dalam dunia wirausaha gagal lalu berhenti. Terdapat beberapa yang tetap terus mempertahankan usahanya di tengah banyaknya kendala dan hambatan bahkan kegagalan yang dihadapi. Belajar dari pengalaman-pengalaman tersebut akan membantu untuk mencapai hasil yang lebih positif di masa yang akan datang, dan keberhasilan merupakan buah dari usaha-usaha yang tidak mengenal lelah tersebut (Meredith, 2000).

Berdasarkan penelitian yang dilakukan oleh Baron (2009) ditemukan bahwa wirausaha yang sudah merasakan berbagai pengalaman sejak merintis usaha hingga dapat berjalan stabil memiliki kemampuan memproses informasi, pengambilan keputusan dan kemampuan kognitif lainnya yang lebih baik daripada wirausaha pemula. Artinya, semakin banyak pengalaman yang dihadapi, individu tersebut semakin lebih dapat mentolerir peluang-peluang berisiko, semakin tahan terhadap situasisituasi stres serta memiliki kemampuan coping stres yang lebih efektif daripada sebelumnya. Salah satu hal yang dapat mempengaruhi tinggi rendahnya stres yang dirasakan oleh seseorang adalah ketangguhan (hardiness). Berdasarkan latar belakang tersebut, peneliti ingin mengetahui ketangguhan (hardiness) pada mahasiswa yang berwirausaha dalam menjalani kehidupannya terutama mahasiswa yang mampu bertahan dan mengembangkan usahanya di tengah berbagai tuntutan peran baik sebagai mahasiswa, wirausaha, dan diri pribadi, sekaligus masih dapat berprestasi dalam berbagai bidang yang ditekuninya.

Individu dapat menghindari situasi-situasi yang menimbulkan stres dan berisiko. Namun dengan begitu individu tersebut juga akan kehilangan kesempatan untuk belajar dan bertumbuh yang mungkin akan membawanya pada kesuksesan (Maddi \& Koshaba, 2005). Terkadang individu juga tidak mampu mencegah datangnya situasi stres, tetapi individu memiliki kemampuan untuk dapat mempengaruhi dampak stres yang dirasakannya, paling tidak mereduksi serta meminimalisasi efek buruk yang dialami. Hardiness telah banyak dipertimbangkan sebagai suatu sikap mental yang dapat mengurangi efek stres secara fisik maupun mental pada individu. Hardiness merupakan salah satu karakter yang dapat mempengaruhi individu tentang bagaimana dirinya melihat sebuah situasi stres dan menentukan respon yang efektif (Odgen, 2007).

Hardiness dapat diartikan sebagai karakteristik kepribadian yang mempunyai fungsi sebagai sumber perlawanan di saat individu menemui suatu kejadian yang menimbulkan stres (Maddi \& Khoshaba, 2005). Menurut Nevid, Rathus, dan Greene (2005), hardiness adalah sekumpulan trait individu yang dapat membantu dalam 
mengelola stres yang dialami. Karakter kepribadian tersebut membuat individu memiliki kecenderungan untuk membentuk hubungan yang positif antara dirinya dengan dunia di luar dirinya. Hardiness tidak hanya keras atau tahan terhadap stres, tetapi sebuah kekuatan untuk keluar dari keadaan-keadaan yang sulit dan keluar dari kondisi stres. Hardiness membantu individu menjadi tabah serta ulet dengan bertahan dan bertumbuh dalam situasi-situasi stres. Kepribadian tersebut dirumuskan dalam 3C yaitu control, commitment, challenge (Maddi \& Khoshaba, 2005).

Karakteristik hardiness menurut Sarafino (2008) adalah control,commitment, dan challenge. Kontrol (control) merupakan keyakinan individu bahwa dirinya dapat mempengaruhi peristiwa dalam kehidupannya. Komitmen (commitment) adalah perasaan individu tentang tujuan hidupnya bahwa dirinya terlibat pada setiap peristiwa, aktivitas, orang-orang dalam kehidupannya.Tantangan (challenge) merupakan kecenderungan untuk melihat perubahan sebagai peluang atau dorongan untuk tumbuh daripada melihatnya sebagai ancaman.

Berdasarkan penelitian yang dilakukan oleh Bruce \& Robert (2009) ditemukan bahwa hardiness memiliki beberapa pengaruh positif antara lain menciptakan emosi positif, semakin berkomitmen terhadap tugas, penyusunan kembali rencana setelah kegagalan dan berkorelasi positif terhadap kesuksesan berwirausaha. Hardiness pada mahasiswa yang berwirausaha dalam penelitian ini dapat diartikan sebagai kemampuan untuk bertahan dalam kondisi yang tidak menentu dan kegigihan menghadapi kegagalan dan rintangan.

Berdasarkan latar belakang dan permasalahan yang telah dipaparkan di atas, muncul pertanyaan inti, bagaimana hardiness pada mahasiswa yang berwirausaha dalam menjalani kehidupannya? Pertanyaan-pertanyaan lain yang juga ingin peneliti ketahui dan berkaitan erat dengan permasalahan penelitian antara lain:

1. Apa saja faktor yang mendorong subjek berwirausaha?

2. Bagaimana proses berwirausaha yang subjek jalani?

3. Apa saja stresor yang diterima subjek sebagai mahasiswa wirausaha?

4. Bagaimana subjek merespon stresor dalam perannya sebagai mahasiswa wirausaha?

5. Bagaimana karakter hardiness yang dimiliki oleh subjek?

6. Bagaimana subjek mengatasi stresor yang dihadapi?

7. Apa saja faktor yang memperkuat dan memperlemah hardiness dalam diri subjek?

8. Bagaimana pengaruh hardiness terhadap kehidupan subjek?

\section{METODE}

Penelitian ini menggunakan pendekatan kualitatif untuk mengeksplorasi hardiness pada mahasiswa yang berwirausaha. Subjek dalam penelitian ini berjumlah dua orang, yaitu TW dan GF. Subjek dipilih berdasarkan kriteria berikut ini:
a. Masih tercatat aktif sebagai mahasiswa S1.
b. Merintis usaha ketika masih menjadi mahasiswa.
c. Usaha yang dilakukan dapat bertahan dan berkembang.
d. Bersedia menjadi subjek penelitian

Metode yang digunakan dalam penelitian ini adalah metode studi kasus karena pertanyaan penelitian berkenaan dengan how dan why, peneliti hanya memiliki sedikit peluang untuk mengontrol 
peristiwa-peristiwa yang akan diselidiki dan fokus penelitiannya terletak pada fenomena kontemporer (masa kini) di dalam konteks kehidupan nyata (Yin, 2002). Penelitian studi kasus tersebut membuat peneliti dapat memperoleh pemahaman utuh dan terintegrasi mengenai interrelasi berbagai fakta dan dimensi dari kasus tersebut.

Pengambilan data dilakukan dengan wawancara, observasi dan dokumentasi (blog). Teknik wawancara digunakan adalah wawancara semi-terstruktur yaitu wawancara berdasarkan pedoman umum yang mencantumkan isu-isu yang harus dibahas tanpa menentukan urutan pertanyaan untuk mendapatkan data (Poerwandari, 2007). Selain melakukan wawancara kepada dua responden, yaitu TW dan GF, peneliti juga melakukan wawancara kepada rekan kerja TW.

Observasi yang digunakan adalah observasi tidak terstruktur yaitu observasi dilakukan tanpa pedoman observasi (Bungin, 2008). Peneliti mengamati subjek penelitian pada situasi kerja dan ketika proses wawancara berlangsung. Beberapa hal yang diobservasi antara lain deskripsi mengenai subjek (kesan umum dan kondisi fisik), deskripsi mengenai setting (tempat, waktu, suasana), perilaku yang ditampakkan, ekspresi verbal dan non verbal. Disamping itu tulisan pada blog pribadi juga menjadi sumber data dalam penelitian ini.

Metode analisis data yang digunakan dalam penelitian ini adalah menggunakan deskripsi fenomena individual (DFI), langkah-langkah yang dilakukan sebagai berikut : 1) Peneliti membuat dan mengatur data yang sudah dikumpulkan, 2) Peneliti membaca dengan teliti data yang sudah diatur, 3) Menuliskan deskripsi pengalaman peneliti di lapangan, 4) Menyusun deskripsi fenomena individual.
Deskripsi fenomena individual (DFI) adalah deskripsi dari transkrip wawancara yang sudah disusun sedemikian rupa, dan sudah dibersihkan dari pernyataan-pernyataan yang tidak relevan dan pengulangan-pengulangan. Langkahlangkah dalam penyusunan DFI antara lain: membuang pernyataan yang diulang-ulang dari transkrip, memisah-misahkan unit makna dengan memberi tanda penggalan berupa garis miring, menghapus unit-unit makna yang tidak relevan, mengelompokkan dan menata kembali unit-unit makna yang relevan sehingga dapat dibaca dan dipahami dengan lebih mudah, dan yang terakhir memberi nomor pada teks DFI untuk memudahkan penelusuran unitunit makna (Subandi, 2009).

Berdasarkan DFI, peneliti kemudian membagi pengalaman subjek ke dalam episode-episode. Masing-masing episode terdiri dari beberapa tema yang merupakan kumpulan dari unit-unit makna. Suatu episode merupakan serangkaian kejadian atau pengalaman di dalam deskripsi yang mempunyai makna khusus dan terikat dengan waktu. Mengidentifikasi episode-episode yang umum bagi seluruh DFI, peneliti perlu membaca DFI tersebut berulang kali dan dengan cermat memahami urutan umum dari sejumlah deskripsi tersebut (Subandi, 2009).

Kegiatan selanjutnya adalah agregasi kategoris yang dimulai dengan kegiatan koding. Koding merupakan proses mengolah materi/informasi menjadi segmen atau kategori tulisan kemudian melabeli kategori-kategori tersebut dengan istilah khusus/kalimat tertentu yang didasarkan pada istilah/bahasa yang benar-benar berasal dari subjek penelitian (Creswell, 2010). Agregasi kategoris ini peneliti lakukan dengan menggunakan teknik eksplikasi tema. Sebuah tema mengacu pada gagasan dasar yang meliputi makna yang diungkapkan 
oleh subjek. Tema-tema dalam setiap episode dieksplikasi melalui refleksi peneliti terhadap DFI dan transkrip asli. Peneliti memberikan penjelasan mengenai tema yang muncul kemudian memberikan kutipan dari pernyataan subjek dari DFI serta memberikan penomoran (Subandi, 2009).

Tahap selanjutnya peneliti menemukan pola-pola Kategoris. Pada tahap ini, kategori atau tema dari masing-masing subjek disatukan untuk menghasilkan pola-pola data yang membantu untuk mengidentifikasi tema- tema umum yang lebih luas sehingga mampu memberikan pemahaman secara menyeluruh. Pada tahap pola-pola kategoris ini, peneliti melakukan sintesis tema yaitu ringkasan dan perpaduan yang koheren dari seluruh tema-tema yang muncul pada setiap subjek. Peneliti menjelaskan tema-tema umum yang muncul pada setiap subjek maupun tema-tema yang unik, yang muncul pada subjek tertentu (Subandi, 2009).

\section{HASIL DAN PEMBAHASAN}

\section{Episode dan Tema}

Berdasarkan deskripsi fenomena individual, peneliti membagi pengalaman kedua subjek ke dalam tiga episode yaitu: episode pra-mahasiswa wirausaha, episode merintis usaha, dan episode memelihara usaha. Episode pramahasiswa wirausaha berisi gambaran kehidupan subjek dalam menjalani masa kanak-kanak hingga dewasa dan kehidupan subjek di awal-awal perkuliahan ketika belum memiliki usaha yang serius. Episode merintis usaha berisi gambaran bagaimana subjek merintis usahanya dan apa saja kesulitan yang dihadapi. Episode memelihara usaha berisi gambaran bagaimana subjek menyikapi masalah, bagaimana memanajemen kehidupan, bagaimana mempertahankan keberjalanan usaha, support system, manfaat yang dirasakan, dan pemahaman diri. Penjabaran episode dengan rincian tema disajikan dalam Tabel 1.

\section{Sintesis}

Berdasarkan pengalaman-pengalaman subjek yang terdapat dalam tema-tema, diketahui bahwa masing-masing subjek memiliki keunikan tersendiri dalam menjalani kehidupan sebagai mahasiswa wirausaha. Namun terdapat juga beberapa kesamaan pada kondisi-kondisi tertentu. Peneliti akan membandingkan tema-tema pengalaman pada tiap subjek dari tiga episode yaitu episode pramahasiswa wirausaha, episode merintis usaha, dan episode memelihara usaha.

Peneliti merinci hardiness pada mahasiswa yang berwirausaha dalam tiga hal, yaitu respon (kondisi stres), karakteristik kepribadian hardiness, dan coping stres. Hal tersebut sesuai dengan definisi hardiness sendiri sebagai sumber perlawanan terhadap stres (Maddi \& Khoshaba, 2005), yang dikarakteristikkan dengan control, commitment, dan challenge (Santrock, 2002), serta dapat membantu individu dalam mengelola stres yang dialami (Nevid dkk, 2005).

\section{Respon (kondisi stres)}

Respon yang ditunjukkan kedua subjek dalam menghadapi kondisi stres terdiri dari respon kognitif, emosi, dan perilaku. Kedua subjek merespon situasi stres dengan respon positif maupun negatif. Respon positif ditunjukkan antara lain dengan ber-positive thinking, berpikir bahwa masalah yg dihadapi masih kecil dan memang harus dilewati, kesadaran untuk konsisten terhadap pilihan, 
Tabel 1. Episode dan Tema

\begin{tabular}{|c|c|c|}
\hline \multirow{2}{*}{ EPISODE } & \multicolumn{2}{|c|}{ TEMA-TEMA } \\
\hline & SUBJEK 1 & SUBJEK 2 \\
\hline $\begin{array}{l}\text { Pra- } \\
\text { Mahasiswa } \\
\text { Wirausaha }\end{array}$ & $\begin{array}{l}\text { 1. Latar belakang kehidupan } \\
\text { 2. Ibu, sosok yang menginspirasi untuk } \\
\text { berwirausaha } \\
\text { 3. Keinginan memenuhi kebutuhan pribadi } \\
\text { sendiri memotivasi untuk berwirausaha } \\
\text { semasa sekolah } \\
\text { 4. Kuliah di UNDIP, langkah awal mewujudkan } \\
\text { mimpi } \\
\text { 5. Organization is my soul }\end{array}$ & $\begin{array}{l}\text { 1. Latar belakang kehidupan } \\
\text { 2. Berkuliah di ITB sarana memperoleh kekayaan } \\
\text { dan mengembangkan diri } \\
\text { 3. Organisasi sebagai sarana menebar manfaat } \\
\text { dan memperbanyak teman } \\
\text { 4. Berjualan ketika teman lain belajar, untuk } \\
\text { mempertahankan hidup } \\
\text { 5. Keluarga sebagai sumber motivasi } \\
\text { berwirausaha }\end{array}$ \\
\hline $\begin{array}{l}\text { Merintis } \\
\text { Usaha }\end{array}$ & $\begin{array}{l}\text { 6. Business is my life } \\
\text { 7. Keberanian dan kecermatan melihat peluang: } \\
\text { modal awal mendirikan khatulistiwa tour and } \\
\text { travel } \\
\text { 8. Learning by doing: prinsip dalam } \\
\text { menjalankan usaha }\end{array}$ & $\begin{array}{l}\text { 6. Titik awal berkeyakinan menjadikan wirausaha } \\
\text { sebagai jalan hidup } \\
\text { 7. Ketidaksengajaan menemukan ide awal } \\
\text { berwirausaha } \\
\text { 8. Pengalaman terpuruk secara mental karena } \\
\text { bisnis } \\
\text { 9. Kegagalan demi kegagalan datang silih } \\
\text { berganti } \\
\text { 10. Kecerdikan melihat peluang dalam } \\
\text { berwirausaha } \\
\text { 11. Memulai langsung adalah cara belajar yang } \\
\text { paling efektif dalam berwirausaha }\end{array}$ \\
\hline $\begin{array}{l}\text { Memelihara } \\
\text { Usaha }\end{array}$ & $\begin{array}{l}\text { 9. Kegagalan sebagai sarana instropeksi dan } \\
\text { bangkit kembali } \\
\text { 10. Mendekatkan diri pada allah sebagai respon } \\
\text { menghadapi permasalahan } \\
\text { 11. Manajemen waktu dan kedisiplinan: cara } \\
\text { mempertahankan keberjalanan kuliah, bisnis, } \\
\text { dan organisasi } \\
\text { 12. Kegiatan sosial sebagai wujud kontribusi } \\
\text { kepada masyarakat } \\
\text { 13. Inovasi kunci pengembangan usaha } \\
\text { 14. Keluarga sebagai sumber kekuatan, teman } \\
\text { sebagai motivator } \\
\text { 15. Banyak hal positif yang dirasakan dengan } \\
\text { berwirausaha } \\
\text { 16. Memahami diri sebagai sarana untuk } \\
\text { melecutkan potensi }\end{array}$ & $\begin{array}{l}\text { 12. Melihat kesulitan-kesulitan dalam } \\
\text { berwirausaha sebagai ujian } \\
\text { 13. Gagal hanya labelisasi orang lain } \\
\text { 14. Menyendiri dan sharing kepada yang ahli, } \\
\text { sebagai cara merespon stres } \\
\text { 15. Keluarga sebagai pembangkit semangat untuk } \\
\text { kembali berjuang } \\
\text { 16. Tidak ada langkah mundur dalam } \\
\text { berwirausaha } \\
\text { 17. Pentingnya manajemen waktu: konsekuensi } \\
\text { yang harus dihadapi antara kuliah, wirausaha, } \\
\text { organisasi } \\
\text { 18. Besarnya bisnis karena kerja tim yang solid } \\
\text { 19. Jalan panjang memperoleh trust dalam } \\
\text { berwirausaha } \\
\text { 20. Dukungan dari keluarga dan teman yang } \\
\text { sangat berarti } \\
\text { 21. Buah dari kerja keras: manfaat yang } \\
\text { dirasakan, pencapaian dan prestasi } \\
\text { 22. Pemahaman diri mempermudah meraih } \\
\text { kesuksesan }\end{array}$ \\
\hline
\end{tabular}


Tabel 2. Sintesa

\section{EPISODE PRA MAHASISWA WIRAUSAHA}

Tema umum 1: Kehidupan subjek dalam menjalani masa kanak-kanak

\begin{tabular}{clll}
\hline No. & Hal & \multicolumn{1}{c}{ Subjek TW } & \multicolumn{1}{c}{ Subjek GF } \\
\hline 1. & Status dalam keluarga & Anak ke 3 dari 7 bersaudara & Anak ke 2 dari 7 bersaudara \\
2. & Status orangtua & Ayah: polisi, Ibu: wirausaha & Ayah: karyawan, Ibu: ibu rumah tangga \\
3. & Kondisi ekonomi keluarga & Menengah & Menengah ke bawah \\
4. & Pola asuh & Ditanamkan kemandirian sejak kecil & \\
& & Penanaman nilai-nilai agama & Penanaman nilai-nilai kedisiplinan \\
5. & Menjalani masa kecil & Tinggal di asrama & Tinggal bersama kakek nenek \\
6. & Precipitating event & Perjuangan ibu berwirausaha & Peristiwa pemberian tas dari bapak \\
7. & Pertama kali berwirausaha & SMP & SD \\
8. & Motivasi berwirausaha di & Memenuhi kebutuhan pribadi sendiri &
\end{tabular}

Tema umum 2: Kegiatan subjek di awal perkuliahan
9. Jurusan kuliah
Teknik Planologi UNDIP
Teknik Material ITB 10. Alasan berkuliah di tempat
tersebut
Ingin membuka jaringan ke seluruh Jalan memperoleh kekayaan
Indonesia dan dunia
11. Kegiatan di awal perkuliahan
Mengikuti organisasi
Merancang pembentukan usaha
Berjualan donat
12. Motivasi berorganisasi
Mengembangkan potensi dan jaringan
Berkumpul, berdiskusi dan
Sarana berdakwah dan menebar manfaat
13. Pola pergaulan memperjuangkan sesuatu
Memilih bergaul dengan kakak-kakak angkatan dari pada dengan teman seangkatan untuk semakin meningkatkan potensi.
14. Cara pandang terhadap kuliah
Kuliah sebagai sarana untuk meningkatkan kompetensi, memperbanyak teman, membentuk pola pikir, melatih manajemen waktu, dan melatih hubungan interpersonal.

\section{EPISODE PRA MERINTIS USAHA}

\section{Tema umum 1: Bagaimana Subjek Merintis Usaha}

15. Pola berwirausaha

16. Unit usaha yang ditekuni

17. Modal awal

18. Cara pandang terhadap wirausaha
Fokus pada satu unit usaha yang sudah dipikirkan secara matang dan mendalam

Khatulistiwa Tour and Travel
Langsung menjalani peluang usaha yang ada di depan mata, jika gagal maka beralih pada usaha lain sampai menemukan yang prospektif dan sesuai dengan passion.

Istana Mug dan Keramik (pending), Soft Ice Cream (bangkrut), Umbi Steak (bangkrut), Raja Mesin Indonesia (bertahan), Agri Mustika Indonesia (bertahan).

Tidak memiliki modal dana sama sekali. Keduanya meminjam kepada teman secara kolektif untuk memulai usaha.

Kekuatan mental dan keberanian Keyakinan mengambil risiko

Sarana mengekspresikan diri, memberikan manfaat bagi orang lain sekaligus dapat menikmati hidup dan menyalurkan hobi
Cara tercepat untuk mendapatkan kekayaan dan kesuksesan, sehingga bisa mengangkat derajat keluarga. 
Tabel 2. Sintesa

(lanjutan)

\begin{tabular}{cll}
\hline No. & Hal & \multicolumn{1}{c}{ Subjek TW } \\
\hline 19. & Faktor pencetus berwirausaha & Bussines is my life \\
20. Proses merintis bisnis & $\begin{array}{l}\text { Melakukan survei dan pematangan } \\
\text { usaha selama } 6 \text { bulan }\end{array}$ \\
21. Misi usaha & $\begin{array}{l}\text { Meningkatkanpariwisata Indonesia, } \\
\text { mengubah image pariwisata dari hanya } \\
\text { fun menjadi plus pembelajaran. }\end{array}$
\end{tabular}

Tema umum 2: Kesulitan yang Dihadapi

\author{
22. Kesulitan dan \\ masalah yang \\ dihadapi
}

\section{Respon}
24. Prinsip berwirausaha
25. Pola kepemimpinan
26. Cara memotivasi karyawan/tim kerja

Masalah kepercayaan dan pengetahuan yang masih terbatas, track record yang masih sedikit, terdapat praktek-praktek penyogokan yang tidak sesuai dengan nilai yang dianut, keuangan yang defisit sehingga tidak bisa menggaji karyawan, beberapa kali mengalami kerugian, salah menghitung, pernah tertipu, dan kecurian mobil.
- Perasaan sedih dan menyesal, mengalami penurunan motivasi
- Berpikir bahwa masalah yang dialaminya masih tergolong masalah yang kecil
- Tidak ada keinginan untuk berhenti bisnis

Learning by doing, Memulai dulu

Tegas namun fun

Menanamkan bahwa berbisnis harus memiliki target, siap bekerja keras, siap lelah, dan senantiasa menikmati segala prosesnya, pahit maupun manis. Kegamangan menatap masa depan
yang tidak pasti.

Awalnya tidak tahu akan berbisnis apa, bisnis awal ditemukan secara tidak sengaja.

Istana Mug dan Keramik: memenuhi keinginan pasar

agri mustika Indonesia: m emajukan agrikultural Indonesia

Tertipu vendor sebesar ratusan juta rupiah, banyak usaha yang akhirnya bangkrut karena kurangnya kemampuan manajerial, mengalami kerugian, kesulitan mendapatkan dan mengembalikan modal, gagal panen pertama kali ketika mendirikan Agri Mustika Indonesia.

- Sempat terpuruk secara mental, merasa tidak mampu menjalani kehidupan sebagai wirausaha, hidup terasa tidak tenang, sering terpikir masalah-masalah bisnis, dan sempat ingin berhenti berwirausaha, namun bangkit lagi.

- Menangis

- Meyakini bahwa tahun-tahun awal memang masa-masa ujian

\section{Kekeluargaan}

Pengusaha sukses juga mengalami kegagalan, maka tidak ada kata menyerah; Memberikan bekal wirausaha pada tiap karyawan

\section{EPISODE MEMELIHARA USAHA}

\section{Tema umum 1: Bagaimana Subjek Menyikapi Masalah}

27. Menyikapi masalah
- Meyakinkan diri bahwa hidup memang penuh risiko dan harus dihadapi

- Berusaha mengambil pelajaran dari kegagalan dan berusaha tidak mengulang kesalahan yang sama

- Mendekatkan diri kepada Allah SWT

- Makan, tidur, menjahili teman
- Menyadari bahwa kerugian adalah hal yang biasa dihadapi oleh para pelaku bisnis

- Memilih untuk tidak begitu saja menyerah bahkan tidak ada jalan lain selain maju dan meneruskan bisnis

- Menenangkan diri dengan cara menyendiri.

- Sharing kepada orang kepercayaan

- Tidak memiliki jalan lain selain terus menjalani dan mengusahakan bisnis yang sudah dirintisnya

- Menanamkan dalam diri bahwa bila mundur, berarti apa yang sudah diusahakan selama ini menjadi sia-sia 
Tabel 2. Sintesa

(lanjutan)

\begin{tabular}{clll}
\hline No. & Hal & \multicolumn{1}{c}{ Subjek TW } & \multicolumn{1}{c}{ Subjek GF } \\
\hline 28. & Cara pandang terhadap & Kegagalan merupakan cara Allah \\
& kegagalan & $\begin{array}{l}\text { untuk membuat bisnisnya semakin } \\
\text { besar }\end{array}$ & $\begin{array}{l}\text { Kegagalan sebagai sesuatu yang belum } \\
\text { tercapai, memang harus dilewati dan ia } \\
\text { akan berjuang untuk melewatinya }\end{array}$ \\
29. & Pembangkit semangat & Keluarga dan kisah hidup pengusaha sukses
\end{tabular}

\section{Tema umum 2: Bagaimana Memanajemen Kehidupan}

30. Pengaruh berwirausaha Perkuliahan terganggu, jadwal bentrok, kelulusan mundur terhadap perkuliahan

Harus mengulang beberapa mata IP turun kuliah

31. Cara mengatasi Manajemen waktu, pendelegasian tugas, menentukan skala prioritas, fokus Manajemen diri, disiplin

Memanfaatkan waktu luang dengan sebaik- baiknya

32. Kegiatan lain Program Wirausaha Binaan, Young and Sekolah pengusaha muda

Tema umum 3: Mempertahankan Keberjalanan Usaha Success Club, Dai Muda Pilihan
33. Kunci kesuksesan
Inovasi dan action

Kepercayaan (trust), track record, dan kerja tim yang solid

\section{Tema umum 4: Support System}

34. Support system

Doa dan dukungan keluarga

- Keluarga memberikan kepercayaan _ $\quad$ Rutin pulang ke rumah kepada subjek untuk berwirausaha

- Rutin saling menelepon teman

\section{Tema umum 5: Manfaat yang Dirasakan}
35. Manfaat yang dirasakan dengan berwirausaha sambil kuliah

36. Prestasi

37. Penghasilan/Omzet

38. Cara pandang terhadap kesuksesan

\section{Tema umum 6: Pemahaman Diri}
39. Potensi
40. Karakter memiliki keberanian, memiliki sikap, dan menjadi lebih dewasa dan bijaksana dalam menghadapi persoalan

- Dapat menyalurkan hobi

- Memiliki banyak waktu luang untuk pengembangan diri dan beribadah

- Menjadi pembicara di acara seminar dan sebagainya.

- Bertemu dengan pengusaha dan orang-orang sukses

- Menjadi mentor bisnis teman-temannya

Berhasil meraih Juara 2 Wirausaha Muda Mandiri 2009

Penghasilan 3-4 juta perbulan

Bila banyak memberikan manfaat. Semakin banyak yang dapat diberikan, maka semakin banyak yang akan mendoakan.
Berhasil meraih Juara 1 ITB Entrepreneurship Award Omzet ratusan juta tiap kali berhasil panen

Bila kehidupan dapat diridloi oleh Allah dengan membuat orangtuabenarbenar bahagia dan dapat menikmati kehidupan serta menebar sebanyakbanyak manfaat dalam kehidupan.
Kekuatan di kemampuan berkomunikasi
- Pribadi yang terbuka dan menyenangkan
- Gigih dan senang mempelajari banyak hal
- Konsisten terhadap pilihan
- Agak ceroboh
- Humoris
- Suka membuat orang lain berpikir seperti apa yang ia pikirkan
- Pencemas terhadap hal-hal yang belum terjadi


Tabel 2. Sintesa

(lanjutan)

\begin{tabular}{|c|c|c|}
\hline $\begin{array}{ll}\text { No. Hal } \\
\end{array}$ & Subjek TW & Subjek GF \\
\hline 41. Cita-cita & $\begin{array}{ll}- & \text { Membuka lagi beberapa } \\
& \text { cabang Khatulistiwa } \\
- & \text { Mengembangkan market di } \\
& \text { Timur Tengah, Dubai dan Arab } \\
& \text { Saudi } \\
- & \text { Mengembangkan usaha di } \\
& \text { bidang Air Lines dan Auto Bus } \\
- & \text { Membuka konsultan perencanaan } \\
& \text { pembangunan kawasan } \\
- & \text { Memiliki rumah untuk yatim } \\
& \text { piatu } \\
- & \text { Menikah dan memiliki anak } \\
- & \text { Membahagiakan orangtua }\end{array}$ & 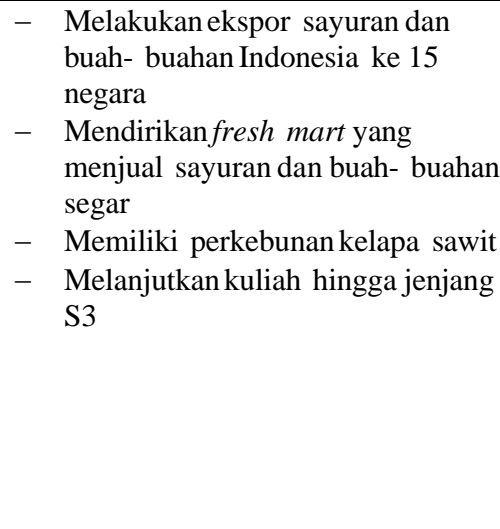 \\
\hline
\end{tabular}

menyadari bahwa hidup memang berisiko dan harus dijalani, menyadari kerugian merupakan hal biasa, meyakini bahwa tahun-tahun awal dalam berwirausaha sebagai tahun ujian, menyadari bahwa kegagalan hanya keberhasilan yang belum tercapai, berusaha untuk mempertahankan spirit berjuang, meyakini bahwa kegagalan adalah cara Allah membuat bisnis semakin besar, mengambil pelajaran dari kegagalan, membaca profil orang sukses, segera bangkit dan melanjutkan usaha, introspeksi diri, dan tidak ada langkah mundur dalam berwirausaha.

Respon negatif yang ditunjukkan subjek antara lain munculnya perasaan sedih, menyesal, merasa turun motivasi, perasaan ingin mengakhiri usaha, merasa hidup tidak tenang, merasa banyak masalah, merasakan beban yang berat, sering terpikir masalah bisnis di mana pun berada, frustasi, shocked, terpukul, motivasi menurun, merasa tidak berbakat wirausaha, menyalahkan diri sendiri, dan menarik diri.

Subjek GF terlihat lebih banyak menunjukkan respon negatif dibandingkan dengan subjek TW, terutama respon emosi. Namun, respon negatif tersebut diimbangi dengan respon positif yang membuat kedua subjek tetap dapat untuk mengatasi serta keluar dari situasi stres tersebut.

Hasil penelitian tersebut sesuai dengan yang diungkapkan (Santrock, 2003), bahwa stres tidak selalu berdampak negatif pada diri individu. Stres juga dapat memberi dampak positif yang disebut eustress. Adanya perbedaan dampak stres pada diri individu disebabkan oleh adanya perbedaan karakteristik masing- masing individu serta kekuatan konsep dirinya yang akhirnya menentukan besar kecilnya toleransi individu tersebut terhadap stres (Anoraga, 2006).

\section{Karakteristik hardiness pada mahasiswa wirausaha}

TW memutuskan untuk memulai berwirausaha sejak di bangku SMP karena ingin dapat mandiri di tengah keterbatasan ekonomi keluarga dan ingin merasakan mempunyai uang hasil keringat sendiri. Semester pertama perkuliahannya, selain aktif di organisasi, TW mulai mempersiapkan dengan matang usaha apa yang akan ditekuninya. GF tahun 2009 memutuskan memilih wirausaha sebagai jalan hidupnya. Hal yang melatarbelakanginya antara lain keaktifannya di organisasi yang membuat IP nya menurun drastis. Hal tersebut 
membuat GF gamang menatap masa depan. Padahal GF memiliki tujuan hidup ingin dapat segera mandiri, meraih kekayaan dan mengangkat derajat keluarganya. GF menetapkan tahun 2009 sebagai titik awal berwirausaha secara serius. Beberapa perilaku yang ditunjukkan oleh subjek TW dan subjek GF tersebut dapat diidentifikasi sebagai karakteristik control yaitu kemampuan untuk mengatur, membimbing, dan memutuskan tingkah laku sendiri.

TW beranggapan bahwa, dengan berwirausaha TW dapat menikmati hidup, dapat banyak memberikan manfaat untuk orang lain, dapat menyalurkan hobi, dan dapat mengekspresikan diri. TW juga beranggapan bahwa salah satu cara untuk menjadi pahlawan Indonesia adalah dengan menjadi pengusaha, karena dapat menciptakan banyak lapangan pekerjaan. Salah satu alasan GF menunda kelulusannya adalah karena GF mengaku bahwa status mahasiswa membantunya untuk mendapatkan kemudahankemudahan dalam berbisnis, misalnya mendapatkan potongan harga, dan mendapatkan ilmu langsung dari ahlinya. Kegagalan berturut-turut yang dialami GF di usaha mug dan keramik malah melecut semangatnya untuk melanjutkan niatnya berwirausaha dan menjalankan kembali usaha Istana Mug dan Keramik. Beberapa perilaku yang ditunjukkan oleh subjek TW dan subjek GF tersebut dapat diidentifikasi sebagai karakteristik control yaitu kemampuan untuk membuat pengaruh positif dari peristiwa yang terjadi.

TW tidak sembarang memilih teman pergaulan. TW meningkatkan level pergaulannya dan memilih teman bergaul 1-4 tingkat di atasnya. Hal tersebut merupakan strategi TW dalam kehidupannya berkampus untuk mengembangkan kompetensinya agar dirinya dapat terpengaruh ke hal-hal yang positif dan membangun. Perilaku yang ditunjukkan oleh subjek TW tersebut dapat diidentifikasi sebagai karakteristik control yaitu kemampuan untuk mengontrol lingkungan eksternal.

Awal terbentuknya Khatulistiwa Tour and Travel, promosi dilakukan dari mulut ke mulut, promosi kepada teman terdekat, kemudian TW dan tim berusaha untuk selalu mengulang-ulang kata-kata Khatulistiwa di mana pun berada, sehingga orang-orang menjadi tahu, mengenal dan pada akhirnya menggunakan jasa Khatulistiwa Tour and Travel. Ketika TW belum dapat menggaji karyawan karena keuangan perusahaan yang sedang defisit, yang dilakukannya mengkomunikasikan dengan sebaikbaiknya kepada karyawan. GF dalam memulai usaha lebih memilih memulai apa yang ada dan apa yang dapat dilakukan daripada mendewakan idealisme yang pada akhirnya membuat tidak terealisasikannya sebuah bisnis, walaupun tanpa ketersediaan modal dan keterbatasan pengetahuan. Beberapa perilaku yang ditunjukkan oleh subjek TW dan subjek GF tersebut dapat diidentifikasi sebagai karakteristik control yaitu kemampuan bertindak secara konkret untuk mengatasi suatu permasalahan.

Ketika awal mendirikan Khatulistiwa Tour and Travel, TW berusaha untuk berpikir positif bahwa usaha tersebut akan berjalan bagus dan memiliki masa depan yang cerah. Hal tersebut yang membuat TW yakin meminjam uang kepada temantemannya sebagai modal. Ketika menghadapi permasalahan, yang dilakukan TW adalah berusaha untuk berpikir masalah yang dialami tersebut masih tergolong masalah yang kecil, apalagi umur bisnis TW yang tergolong masih sangat muda. GF meyakini bahwa tahun-tahun awal berbisnis memang merupakan masa-masa ujian di mana 
memang banyak cobaan untuk menguji seberapa tangguh dirinya. Setelah masamasa tersebut terlewati, maka GF akan lebih dapat menggunakan kepekaannya dalam 'mencium suatu bisnis'. Beberapa perilaku yang ditunjukkan oleh subjek TW dan subjek GF tersebut dapat diidentifikasi sebagai karakteristik control yaitu kemampuan untuk menggunakan proses kognitif untuk memodifikasi dampak negatif dari suatu peristiwa.

Sebelum berdirinya Khatulistiwa, TW dan tim melakukan persiapan selama enam bulan yang disebut TW sebagai masa inkubasi. Masa inkubasi tersebut, TW melakukan survei ke tempat-tempat wisata dan mempelajari berbagai macam infomasi mengenai bisnis di bidang tour and travel. Setelah memutuskan wirausaha sebagai jalan hidup, GF masih bingung akan memulai usaha di bidang apa. Hal tersebut disebabkan karena ketidaktahuan GF akan ilmu- ilmu berwirausaha. Ketidaktahuan tersebut membawa GF belajar pada orang- orang yang sudah ahli dan lebih dahulu terjun di dunia tersebut. Beberapa perilaku yang ditunjukkan oleh subjek TW dan subjek GF tersebut dapat diidentifikasi sebagai karakteristik control yaitu kemampuan untuk mengumpulkan informasi mengenai sesuatu hal/peristiwa.

Sarafino (2008) berpendapat bahwa control merupakan keyakinan individu bahwa dirinya dapat mempengaruhi peristiwa dalam kehidupannya. Individu dengan control yang kuat terus berusaha membuat pengaruh positif dari perubahan yang terjadi daripada membiarkan diri tenggelam dalam kepasifan dan ketidakberdayaan. Berdasarkan hasil penelitian, peneliti menemukan indikator control lain pada mahasiswa yang berwirausaha yaitu (1) kemampuan untuk mengatur, membimbing, dan memutuskan tingkah laku sendiri; (2) kemampuan untuk mengontrol lingkungan eksternal; (3) kemampuan bertindak secara konkret untuk mengatasi suatu permasalahan; (4) kemampuan untuk menggunakan proses kognitif untuk memodifikasi dampak negatif dari suatu peristiwa; (5) kemampuan untuk mengumpulkan informasi mengenai sesuatu hal/peristiwa.

TW menerapkan target-target dalam berbisnis, seperti berapa omzet yang harus dicapai pada tahun tersebut, berapa profit yang harus diraih, berapa karyawan yang harus diterima. GF sangat memperhatikan karyawan dalam menjalankan semua bisnisnya terutama mengenai gaji dan kesejahteraan. GF juga memberikan bekal kewirausahaan kepada karyawan tersebut, sehingga diharapkan suatu saat karyawan-karyawan tersebut dapat mandiri. Beberapa perilaku yang ditunjukkan oleh subjek TW dan subjek GF tersebut dapat diidentifikasi sebagai karakteristik commitment yaitu aktif terlibat dalam berbagai aktivitas yang djalaninya serta orang-orang di sekitarnya.

Hal yang membuat TW mantap mendirikan Khatulistiwa Tour and Travel tersebut adalah keyakinan bahwa TW telah memilih jalan tersebut dan yakin akan sukses. Alasan TW memilih usaha di bidang tour and travel tersebut adalah karena melihat bisnis tersebut memiliki peluang yang besar dan bagus. GF senantiasa melihat faktor profit yang akan diperoleh dari tiap usaha yang akan ditekuninya. GF berpendapat bahwa bisnis merupakan permainan uang, di mana uang yang diinvestasikan akan menghasilkan jumlah yang lebih. Beberapa perilaku yang ditunjukkan oleh subjek TW dan subjek GF tersebut dapat diidentifikasi sebagai karakteristik commitment yiatu berorientasi pada masa depan dalam melakukan setiap aktivitasnya. Perilaku commitment lainnya yang ditunjukkan subjek yaitu: 
Melalui Khatulistiwa, TW memiliki keinginan untuk mengubah image dunia pariwisata yang identik dengan hura-hura menjadi sesuatu yang juga bernilai edukasi. Bagi TW, tidak ada kata menyerah dalam berwirausaha, tetap harus berjuang sampai perusahaan menjadi besar, karena sejak awal TW memang sudah yakin atas pilihan, maka harus konsisten terhadap pilihan tersebut. Salah satu motivasi GF berwirausaha adalah ingin dapat lebih cepat membantu orangtuanya, membayar kuliahnya sendiri, membantu perekonomian keluarga, membantu menyekolahkan adik-adiknya. Motivasi GF dalam berwirausaha lainnya adalah ingin mengangkat derajat keluarga khususnya bapaknya yang dalam keluarga besar menurut GF sering direndahkan karena kondisi ekonomi yang lemah. Alasan tersebut membuat GF pantang menyerah memperjuangkan bisnisnya. Beberapa perilaku yang ditunjukkan oleh subjek TW dan subjek GF tersebut dapat diidentifikasi sebagai karakteristik commitment yaitu melihat apa yang dikerjakannya sebagai sesuatu yang penting dan bermanfaat serta memerlukan perhatian dan usaha yang keras.

TW pada awalnya merupakan orang yang suka belajar dan ingin menjadi akademisi sejati, namun setelah memutuskan untuk berwirausaha, maka TW harus serius pada bidang tersebut dan konsisten serta fokus terhadap pilihannya. TW dalam menjalankan usahanya, berusaha untuk selalu jujur, memberikan yang terbaik, dan konsisten antara apa yang telah dibicarakan dan dijanjikan dengan apa yang akan diupayakan di lapangan. Salah satu alasan GF tidak berhenti berwirausaha adalah GF sangat memikirkan nasib keluarganya. GF ingin segera dapat membalas budi orangtua dan ingin segera membuat orangtua bangga. GF sadar untuk mewujudkannya diperlukan usaha yang lebih keras. Beberapa perilaku yang ditunjukkan oleh subjek TW dan subjek GF tersebut dapat diidentifikasi sebagai karakteristik commitment yaitu menyatu dengan tugas, pekerjaan, dan kehidupan serta memiliki tanggung jawab terhadapnya.

Sarafino (2008) berpendapat bahwa commitment adalah perasaan individu tentang tujuan hidupnya bahwa dirinya terlibat pada setiap peristiwa, aktivitas, orang-orang dalam kehidupannya. Individu dengan commitment yang tinggi tersebut memiliki kecenderungan berorientasi pada masa depan dalam memulai setiap aktivitasnya dan menyukai menjalin hubungan interpersonal dengan orang-orang di sekitarnya. Berdasarkan hasil penelitian, peneliti menemukan indikator commitment lain pada mahasiswa yang berwirausaha yaitu Melihat apa yang dikerjakannya sebagai sesuatu yang penting dan bermanfaat serta memerlukan perhatian dan usaha yang keras, (2) Menyatu dengan tugas, pekerjaan, dan kehidupan serta memiliki tanggung jawab terhadapnya.

Bagi TW, bila tantangan yang datang semakin besar, maka berarti perusahaan juga akan semakin besar, maju, dan berkembang. Hal tersebut yang membuat TW dan tim tetap mempertahankan spirit untuk berjuang. GF melihat kegagalan bukan sebagai kegagalan, tetapi sesuatu yang belum tercapai saja, dan dirinya akan berjuang untuk mewujudkannya. GF menyadari bahwa bisnis bersifat amplitudo. Beberapa perilaku yang ditunjukkan oleh subjek TW dan subjek GF tersebut dapat diidentifikasi sebagai karakteristik challenge yaitu kemampuan melihat perubahan sebagai tantangan menuju kemajuan.

Semester kedua di bangku perkuliahan, TW bersama teman-temannya mendirikan 
bisnis baru bernama Khatulistiwa Tour and Travel yang persiapannya dilakukan selama 6 bulan dengan tanpa ketersediaan modal. TW berani meminjam modal secara kolektif kepada teman-temannya sebesar Rp 15 juta dan berjanji akan mengembalikan secepatnya. GF dalam kebingungannya memulai untuk berwirausaha, dipertemukan dengan temannya yang mencari tempat membuat mug dari keramik sampai tiga kali bertanya pada waktu yang berbeda. GF berpikir bahwa jika memang di tempat tersebut tidak ada yang dapat membuat mug keramik, mengapa bukan saya saja. Akhirnya GF menerima proyek tersebut. GF juga menjalankan bisnis franchise umbi steak sampai memiliki 4 cabang serta bisnis soft ice cream di tengahtengah berbisnis mug dan Keramik. Beberapa perilaku yang ditunjukkan oleh subjek TW dan subjek GF tersebut dapat diidentifikasi sebagai karakteristik challenge yaitu berani mengambil dan menghadapi situasi berisiko.

TW beranggapan bahwa kesiapan mental dan keberanian merupakan sesuatu yang penting dalam merintis Khatulistiwa. Keberanian untuk mengubah sikap, mengubah diri, dan rencana hidup. TW berusaha membangun common value bahwa berbisnis harus mempunyai target, harus siap lelah, harus siap kerja. GF sangat memperhatikan kedisiplinan dalam pengembalian modal. GF tidak ingin mematahkan kepercayaan yang sedang dibangunnya. Bagi GF, bila investor sudah tidak percaya, maka akan sangat merugikan diri dan usaha yang dibangunnya. Beberapa perilaku yang ditunjukkan oleh subjek TW dan subjek GF tersebut dapat diidentifikasi sebagai karakteristik challenge yaitu mengantisipasi situasi berisiko sebagai peluang pembelajaran dan sarana untuk berkembang.
Setelah terjun di dunia bisnis, TW menjadi tahu bahwa dalam dunia bisnis penuh dengan penyogokan dan uang-uang suap. Hal tersebut dianggap TW sebagai tantangan karena di satu sisi subjek berusaha untuk membuat perusahaan tetap dapat berjalan namun di sisi lain tetap harus menerapkan etika bisnis yang dianut perusahaan. TW tidak lantas memutuskan untuk berhenti berbisnis tetapi memilih untuk menghindari praktek negatif tersebut. Perilaku yang ditunjukkan oleh subjek TW tersebut dapat diidentifikasi sebagai karakteristik challenge yaitu bersahabat dengan tantangan hidup serta tidak menyangkal dan menghindarinya.

Bagi TW, tidak ada kata menyerah dalam berwirausaha, tetap harus berusaha sampai perusahaan menjadi besar. Di sisi lain, kerugian di bisnis Istana Mug dan Keramik tidak menyurutkan semangat GF untuk berwirausaha, terbukti melalui usaha soft ice cream dan umbi steak yang dibukanya. Kegagalan karena bisnis soft ice cream dan umbi steak harus bangkrut tidak menyurutkan semangat GF untuk kembali membuka usaha baru yaitu Raja Mesin Indonesia dan Agri Mustika Indonesia. Beberapa perilaku yang ditunjukkan oleh subjek TW dan subjek GF tersebut dapat diidentifikasi sebagai karakteristik challenge yaitu pantang menyerah dalam menghadapi tantangan.

Kerugian dan kegagalan yang dihadapi TW dalam mengembangkan usaha Khatulistiwa membuatnya mengambil pelajaran dari kegagalan tersebut, di mana titik lemahnya, sehingga ke depannya akan berusaha untuk tidak mengulang kesalahan yang sama. Kegagalankegagalan dalam menjalankan suatu usaha membuat GF semakin lama menjadi semakin dapat mencium bisnis mana yang prospektif dan sesuai passionnya. Beberapa perilaku yang ditunjukkan oleh 
subjek TW dan subjek GF tersebut dapat diidentifikasi sebagai karakteristik challenge yaitu belajar dari kegagalan dan ketidakpuasan untuk melakukan yang lebih baik di waktu yang akan datang.

TW selain aktif berwirausaha dan berorganisasi, juga senang melakukan pengembangan diri seperti mengikuti pelatihan public speaking, berbagai lomba di bidang non bisnis seperti HNMUN (simulasi sidang PBB, kompetisi Dai Muda Pilihan AnTV, kompetisi di bidang penelitian, mendirikan Young and Success Club, dan lain-lain. Awalnya GF tidak diijinkan berwirausaha oleh orangtuanya, tetapi GF memutuskan untuk terus melangkah karena GF menganggap apa yang menjadi pilihannya tersebut baik. Akhirnya, orangtua merestui GF dan membebaskan GF memilih jalan hidup sendiri. Beberapa perilaku yang ditunjukkan oleh subjek TW dan subjek GF tersebut dapat diidentifikasi sebagai karakteristik challenge yaitu termotivasi dan melakukan sesuatu sesuai kata hati.

Sarafino (2008) berpendapat bahwa challenge merupakan kecenderungan untuk melihat perubahan sebagai peluang atau dorongan untuk tumbuh daripada melihatnya sebagai ancaman. Berdasarkan hasil penelitian, peneliti menemukan indikator challenge lain pada mahasiswa yang berwirausaha yaitu (1) Berani menghadapi situasi berisiko; (2) Mengantisipasi situasi berisiko sebagai peluang pembelajaran dan sarana untuk berkembang; (3) Bersahabat dengan tantangan hidup serta tidak menyangkal dan menghindarinya; (4) Pantang menyerah dalam menghadapi tantangan;, (5) Belajar dari kegagalan dan ketidakpuasan untuk melakukan yang lebih baik di waktu yang akan datang; (6) Termotivasi dan melakukan sesuatu sesuai dengan kata hati.
Penelitian lain tentang hardiness dilakukan oleh Hamzah (2009) yang berjudul Ketabahan Mualaf menemukan beberapa indikator control dari hardiness yaitu self control, sense of control, dan self motivation. Indikator commitment yaitu efikasi diri, aktualisasi diri, harapan, dan tanggung jawab. Indikator challenge yaitu kemandirian, asertif, mengungkapkan identitas, dan melawan. Hasil penelitian tersebut nampak jelas berbeda dengan temuan peneliti tentang indikator masing-masing karakteristik dari hardiness mahasiswa yang berwirausaha. Indikator control yang dapat diidentifikasi, yaitu (1) kemampuan untuk mengatur, membimbing, dan memutuskan tingkah laku sendiri; (2) kemampuan untuk membuat pengaruh positif dari peristiwa yang terjadi; (3) k emampuan untuk mengontrol lingkungan eksternal; (4) kemampuan bertindak secara konkret untuk mengatasi suatu permasalahan; (5) kemampuan untuk menggunakan proses kognitif untuk memodifikasi dampak negatif dari suatu peristiwa; (6) kemampuan untuk mengumpulkan informasi mengenai sesuatu hal/peristiwa.

Indikator commitment yang dapat diidentifikasi, yaitu (1) secara aktif terlibat dalam berbagai aktivitas yang djalaninya serta orang-orang di sekitarnya, (2) berorientasi pada masa depan dalam melakukan setiap aktivitasnya; m elihat apa yang dikerjakannya sebagai sesuatu yang penting dan bermanfaat serta memerlukan perhatian dan usaha yang keras; (4) menyatu dengan tugas, pekerjaan, dan kehidupan serta memiliki tanggung jawab terhadapnya.

Indikator challenge yang dapat diidentifikasi, yaitu (1) kemampuan melihat perubahan sebagai tantangan menuju kemajuan; (2) berani menghadapi situasi berisiko; (3) mengantisipasi situasi 
berisiko sebagai peluang pembelajaran dan sarana untuk berkembang; (4) bersahabat dengan tantangan hidup serta tidak menyangkal dan menghindarinya; (5) pantang menyerah dalam menghadapi tantangan; (6) belajar dari kegagalan dan ketidakpuasan untuk melakukan yang lebih baik di waktu yang akan datang; (7) termotivasi dan melakukan sesuatu sesuai dengan kata hati.

Hardiness yang merupakan karakteristik kepribadian mempunyai fungsi sebagai sumber perlawanan di saat individu menemui suatu kejadian yang menimbulkan stres. Hardiness membantu individu menjadi resilient (tabah dan ulet) dengan bertahan dan bertumbuh dalam situasi-situasi stres (Maddi \& Khoshaba, 2005).

Berdasarkan hasil wawancara, masingmasing subjek memiliki keseluruhan karakteristik hardiness namun dalam kadar yang berbeda. Subjek TW terlihat lebih kuat dalam kontrol. Hal tersebut nampak dari keketatannya melakukan kontrol terhadap seluruh dimensi kehidupan, mulai dari aktivitas yang dilakukannya, teman pergaulan, kehidupan perkuliahan dan organisasi, kehidupan berwirausaha, dan masa depan yang ingin dijalani. Control dalam diri subjek GF terlihat tidak sekuat pada diri TW. Subjek GF terlihat lebih kuat dalam challenge. Hal tersebut nampak dalam keberaniannya mengambil risiko dalam memulai usaha dan sifat pantang menyerah terhadap berbagai rintangan dan hambatan yang dihadapinya. Karakteristik commitment pada kedua subjek terlihat sama kuat. Hal tersebut nampak dari kekonsistenan dan kesungguhan kedua subjek menjalankan semua peran-peran dan memenuhi semua tuntutan sesuai dengan porsinya.

\section{Coping stres}

Berdasarkan hasil wawancara, terdapat beberapa cara yang dilakukan subjek sebagai mahasiswa wirausaha dalam melakukan coping, baik problem focused coping maupun emotional focused coping, antara lain dengan manajemen waktu, pendelegasian tugas, manajemen diri, fokus pada apa yang sedang dikerjakan, sharing kepada mentor bisnis, mengambil risiko, pembagian kerja, melakukan apa yang disukai (makan, tidur, menjahili orang, menonton bioskop, jalan-jalan ke mall, bepergian sendiri), menanamkan pada dirinya untuk senantiasa menikmati setiap proses, mengadu dan mendekatkan diri pada Allah dengan memperbanyak sholat malam, mengaji, serta menangis, jika permasalahan yang dihadapi berat.

Emotional-focused coping membantu subjek merasa lebih rileks, tenang, dan tetap enjoy dalam menghadapi permasalahan. Metode coping tersebut juga membantu subjek menyalurkan emosi atau energi negatif. Subjek GF mengaku dengan menyendiri dan melakukan hal yang disukainya dapat membuatnya melupakan sejenak masalah yang dihadapi. Subjek TW lebih memilih untuk mendekatkan diri kepada Allah yang membuatnya tetap kuat dalam menghadapi setiap persoalan dan melaksanakan rencana-rencana besarnya. Ketika individu telah merasa tenang dan dapat mengekspresikan serta menyalurkan emosi negatifnya dengan tepat, maka individu tersebut lebih siap untuk melakukan strategi problem-focused coping untuk menyelesaikan secara konkret permasalahan yang dihadapinya.

\section{KESIMPULAN}

Menjalankan peran sebagai mahasiswa sekaligus wirausaha, terdapat beberapa stresor yang dihadapi baik dari per- 
masalahan usaha maupun interaksi antara peran wirausaha sekaligus mahasiswa. Stresor tersebut antara lain keterbatasan pengetahuan, keterbatasan modal, keterbatasan kemampuan manajerial, keuangan yang defisit, karyawan yang kurang kompeten, kerugian, dan kegagalan, sedangkan stresor dari interaksi peran wirausaha dan mahasiswa antara lain jadwal yang bentrok, membolos kuliah, dan kelulusan yang mundur. Menghadapi stresor-stresor tersebut, masing-masing individu memiliki respon yang berbedabeda, baik kognisi, emosi dan perilaku.

Hardiness pada mahasiswa wirausaha membuat individu memiliki kontrol yang kuat terhadap kehidupan yang akan dijalaninya. Rintangan yang menghadang tidak dilihat sebagai sesuatu yang mengancam, tetapi sebagai tantangan dan pembelajaran untuk semakin dapat meningkatkan kualitas diri. Mempertahankan sebuah usaha cenderung lebih sulit daripada mendirikan dan memulainya. Semakin jauh individu tersebut melangkah, maka akan semakin banyak rintangan yang akan dihadapinya. Individu tersebut dituntut untuk selalu berpikir kreatif dan inovatif dalam melakukan pengembangan usaha.

Hardiness dipengaruhi oleh beberapa faktor, yang terdiri dari faktor penguat dan faktor pelemah. Faktor penguat hardiness pada mahasiswa wirausaha antara lain minat, locus of control internal, pemahaman diri yang baik, pola pikir positif, banyaknya pengalaman yang dihadapi, kemampuan pengambilan keputusan yang baik, kemampuan manajemen waktu yang baik, dan dukungan sosial, sedangkan faktor pelemahnya adalah kesulitan atau permasalahan yang kerap datang secara bertubi-tubi dan terus menerus.

Hasil dari strategi coping yang dilakukan mahasiswa wirausaha adalah kesuksesan yang berhasil diraih baik dalam peran wirausaha maupun peran mahasiswa. Kesuksesan dalam bidang usaha dapat diukur melalui perkembangan usaha itu sendiri ke arah yang lebih baik, inovasiinovasi yang berhasil dilakukan, maupun prestasi-prestasi yang berhasil diraih. Manfaat lain yang dirasakan individu mahasiswa wirausaha yang memiliki hardiness adalah memiliki kesempatan untuk mengontrol jalan hidup sendiri dan memiliki kemerdakaan untuk mengambil keputusan dan risiko, memiliki kesempatan menggunakan kemampuan dan potensi pribadi secara penuh dan aktualisasi diri untuk mencapai cita-cita, memiliki kesempatan untuk meraih keuntungan tak terhingga dan masa depan yang lebih baik, memiliki kesempatan untuk memberikan sumbangan kepada masyarakat dengan lapangan pekerjaan dan pengabdian, menjadi lebih antusias dan energik dari hari ke hari, menjadi lebih terlibat pada apa saja yang dilakukannya, yakin dapat membuat suatu perubahan ke arah positif, memiliki optimisme yang tinggi terhadap apa yang akan terjadi di masa depan, dan kesehatan diri baik fisik maupun psikis dapat lebih terjaga.

\section{DAFTAR PUSTAKA}

Anonim. (2011). Daftar proposal lolos seleksi tahap 1 program mahasiswa wirausaha undip tahun 2011. Diakses dari http://bak.undip.ac.id

Anonim. (2011). Pengangguran terbuka*) menurut pendidikan tertinggi yang ditamatkan 2004, 2005, 2006, 2007, 2008, 2009 dan 2010. Diakses dari http://www.BPS.go.id.

Anoraga, P. (2006). Psikologi kerja. Jakarta: Rineka Cipta. 
Anoraga, P. \& Sudantoko, D. (2002). Koperasi, kewirausahaan, dan usaha kecil. Jakarta: Rineka Cipta.

Baron, R. A. (2009). Effectual versus predictive logics in entrepreneurial decision making: Differences between experts and novices does experience in starting new ventures change the way entrepreneurs think? Perhaps, but for now, "caution" is essential. Journal of Business Venturing, 24, 310-315.

Brandstatter, H. (2011). Personality aspects of entrepreneurship: A look at five meta-analyses. Journal of Personality and Individual Differences, 51, 222230.

Bruce, R. A. \& Robert, F. S. (2009). Exploring the psychological hardiness of entrepreneurs. Presented at the Babson Entrepreneurship: University of Louisville.

Bungin, B. (2007). Metodologi penelitian sosial. Surabaya: Airlangga University Press.

Chaplin, J. P. (2005). Kamus lengkap psikologi. Jakarta: Raja Grafindo Persada.

Creswell, J. W. (2010). Research design: Pendekatan kualitatif, kuantitatif, dan mixed. Yogyakarta: Pustaka Pelajar.

Hamzah, I. (2009). Ketabahan mualaf. Skripsi. Tidak diterbitkan.

Hisrich, R. D., Peters, M. P. \& Shepherd, D. A. (2008). Entrepreneurship: Kewirausahaan. Jakarta: Salemba Empat.
Maddi, S. R. \& Khoshaba, D. M. (2005). Resilience at work. New York: Amacom.

Maddi, S. R. (2002). The story of hardiness: Twenty years of theorizing, research, and practice. Consulting Psychology Journal: Practice and Research, 54(3), 175-185.

Meredith, G. G. (2000). Kewirausahaan teori dan praktek. Jakarta: Pustaka Binaman Presindo.

Moleong, L. J. (2004). Metodologi penelitian kualitatif. Bandung: Remaja Rosdakarya.

Nevid, J. S., Rathus, S. A., \& Greene, B. (2005). Psikologi abnormal. Terjemahan. Jakarta: Erlangga.

Odgen, J. (2007). Health psychology. New York: Open University Press.

Poerwandari, E. K. (2001). Pendekatan kualitatif untuk penelitian perilaku manusia. Jakarta: Lembaga Sarana Pengukuran dan Pendidikan Psikologi (LPSP3) UI.

Riyanti, B. P. D. (2003). Kewirausahaan dari sudut pandang psikologi kepribadian. Jakarta: Gramedia.

Santrock, J. W. (2002). Life span development. Jakarta: Erlangga.

Santrock, J. W. (2003). Adolescence: Perkembangan remaja. Jakarta: Erlangga.

Sarafino, E. P. (2006). Health psychology: Biopsychosocial interaction second edition. New York: John Willey \& Sons Inc. 
Subandi. (2009). Psikologi dzikir: Studi fenomenologis pengalaman transformasi religius. Yogyakarta: Pustaka Pelajar.

Uno, S.S. (2008). Bagaimana cara menjadi pengusaha. Diakses dari: http://pengusahamuda.wordpress.com /2008/07/05/bagaimanacaramenjadipe ngusaha/

Yin, R. K. (2002). Studi kasus desain \& metode. Jakarta: Raja Grafindo Perkasa. 